\title{
Online Review Analysis Triggering Hype in the Motion Picture Industry
}

\author{
T R Laheba" ${ }^{* 1}$ P W Anggoro² \\ ${ }^{1,2}$ Universitas Atma Jaya Yogyakarta, Indonesia \\ E-mail: timothylaheba@gmail.com¹,wisnu.anggoro@uajy.ac.id ${ }^{2}$
}

Submitted: 18 June 2021, revised: 28 July 2021, accepted: 1 August 2021

\begin{abstract}
Abstrak. Persaingan di industri film terus meningkat dengan sangat cepat. Fenomena ini membuat rumah produksi terus mencari cara baru untuk memaksimalkan pendapatan dari siklus hidup film yang singkat. Salah satu variabel yang saat ini memainkan peran yang lebih besar dalam pengambilan keputusan untuk menonton film adalah ulasan. Dua jenis ulasan sering digunakan dalam industri film, yaitu ulasan dari kritikus dan sesama konsumen. Penelitian ini mencoba untuk melihat ulasan siapa yang akan memicu sensasi yang sangat dibutuhkan dalam industri film. Data dari 219 responden dikumpulkan untuk melihat tanggapan mereka mengenai ulasan dan ulasan siapa yang akan mendorong mereka untuk berbicara tentang film kepada rekan-rekan mereka dan akhirnya menciptakan sensasi yang dibutuhkan oleh sebuah film. Ada perbedaan persepsi terhadap ulasan yang diberikan oleh kritikus dan sesama konsumen, bahwa review dari sesama konsumen memiliki potensi yang lebih besar untuk menciptakan dan memicu sensasi di industri film.
\end{abstract}

Kata kunci: ulasan ahli; ulasan konsumen; industri film; sensasi; pemasaran

\begin{abstract}
Competition in the motion picture industry continues to intensify at a very rapid pace. This phenomenon makes the production house continue to look for new ways to maximize revenue from the short life cycle of a film. One of the variables currently playing a larger role in decision-making to watch a film is a review. Two types of reviews are often used in the motion picture industry, namely the reviews from critics and fellow consumers. This study tries to see whose review will trigger a hype or buzz that is much needed in the motion picture industry. Data from 219 respondents were collected to see their response regarding a review and whose review will encourage them to talk about a film to their peers and ultimately create the hype needed by a film. There are different perceptions on reviews given by critics, and reviews from fellow consumers, that reviews from fellow consumers have greater potential to create and ignite hype in the motion picture industry.
\end{abstract}

Keywords: expert review; consumer review; motion picture industry; hype; buzz marketing

\section{Introduction}

Marketing strategy has developed very rapidly. Marketing is a bridge between satisfied consumers and management or companies to seek the most significant profit for industry [1]. The rapid development of marketing due to the emergence of the internet makes an industry have so many choices in determining a marketing strategy for a product for the intended market segment. The marketing strategy of each industry will be very different and specific depending on the type of product and market 
characteristics that the industry owns. Good marketing will provide a competitive advantage for the industry when compared to its competitors. With competition in the industrial world that is increasingly intense, it is a must for enterprises to have an appropriate marketing strategy for their products.

Marketing in the motion picture industry can be done in various ways. Marketing methods for a film can be done offline and online. Offline marketing can be done by using posters, promotion of trailers on billboards or cinema screens, print media, advertisements on television, outdoor advertisements, events to increase publicity, and film previews or press conferences. Meanwhile, the online marketing of films can be done with a review process carried out on various platforms, social media, online posters, and online advertising [2]. These strategies can be carried out by film studios independently or by hiring a marketing agency to do it for them.

The motion picture industry around the world continues to grow very rapidly. There were only two centers of the film industry in the past which films were known and screened worldwide, namely Hollywood and Bollywood. However, in this era of information there is almost no marketing limit for a product including in film marketing. One proof of this is the historic victory of film Parasite as the best film at the 2020 Oscars, which shows the broader reach of a movie from countries that previously were not major players in this industry. This phenomenon encourages the massive growth of the film industry. Throughout 2019, North America, which has Hollywood as the main center of the world motion picture industry, produced 786 films [3]. This output is also coupled with so many movies released from other countries. This phenomenon provides an increasingly diverse choice for consumers in Indonesia in choosing the film that best suits their needs and desires.

Competition in the motion picture industry in Indonesia is highly competitive. Worldwide, Indonesia is ranked 15th regarding revenue from the box office, with a projection to become one of the countries with the most significant revenue in Asia [4]. The growth of cinema screens in Indonesia has reached 600 units in just the last three years [5]. Data on the development of cinema screens in Indonesia can be seen in Figure 1. However, this condition is still far from ideal. For comparison, per capita screen data for China is 1.8 screens per 100,000 people, the United States is at 14 screens per 100,000 people, while Indonesia is only 0.4 screens per 100,000 people [6]. This condition causes the competition to be very tight because there will be so many films competing to be shown on the cinema screen. The cinema owners will be very concerned about the profit and income received from a movie given the slot and the opportunity to appear in each cinema screen.

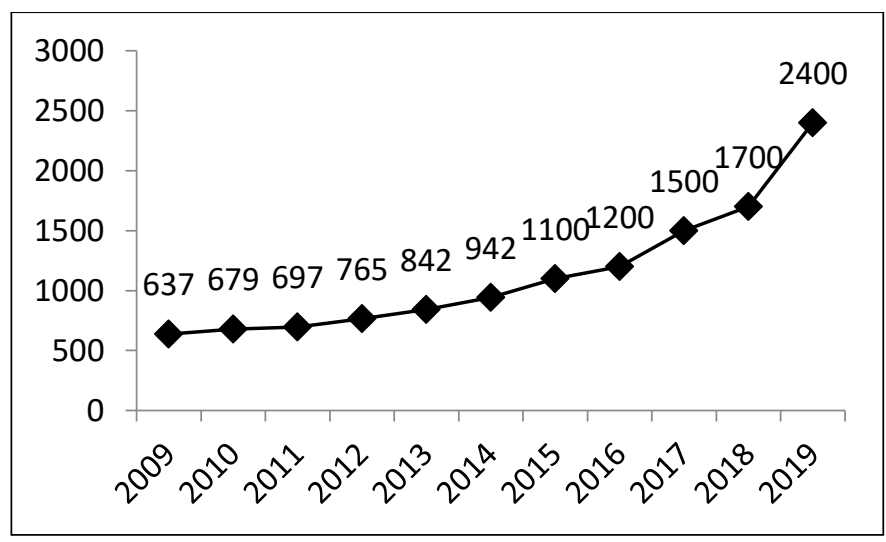

Figure 1. Growth in the Number of Cinemas in Indonesia

The life cycle of a product will significantly affect the strategy that will be applied to maximize revenue. Each product will have four phases in its life cycle: the introduction period, growth period, maturity, and decline. Understanding the life cycle of a product will help industry players determine the right approach regarding pricing, promotion, and distribution of the products produced [7]. The longer the product's life cycle, the higher the potential income that this product will receive. On the contrary, the shorter the product's life cycle, the smaller the potential income. 
Films have a very short product life cycle. In contrast to products in other industries whose life cycle can reach months or years, films will usually only circulate in the market in a matter of weeks. Although there is now a new revenue stream for the motion picture industry in streaming films, ticket sales at cinemas are still the main backbone of revenue for the motion picture industry [8]. This short life cycle will force the motion picture industry players to find the most appropriate ways and marketing strategies to maximize revenue from the films produced.

The hype or buzz is an important factor that can determine the success of a film. The motion picture industry is very dependent on the excitement that is going on in the market when films are about to be released and are being released. This condition is exacerbated by intense competition due to the number of cinema screens that are not ideal in Indonesia. Evaluation of a film is carried out starting from the first day to the fourth day. If a film does not perform well, there is a possibility that the film's circulation period will be very short, considering that there are so many other film choices that can be used as a new source of income for cinema owners [9]. So, if at the beginning of its life cycle a film cannot have satisfactory sales performance, there is a high chance that the film will fail in the market and not provide the profit as expected by the production house that produced it.

Online Reviews can be one of the main triggers for hype or buzz for a product. For example, one industry that uses this approach is the electronics industry, which invites influencers to launch their latest technology product event, hoping that these influencers will later produce a video review related to their product to create hype regarding their product's launch. However, creating hype for the motion picture industry through reviews will be very different from other industries. For example, one way that can be used to create hype for a film is screening a film that will be released before the official release date of the film. It is hoped that from this film screening process, the audience will provide a review which will then create the hype or excitement needed by a film to attract consumer interest. However, film screening has been limited to film critics and influencers, even though it is possible that reviews from consumers can create the hype or buzz needed by this motion picture industry. This study will aim to understand whether the reviews that come from the fellow consumer can also influence the buzz created for a movie to help the movie's production house create a better marketing strategy to maximize revenue and profit from a movie.

\section{Theoretical Framework}

Technology has brought significant changes in the implementation of the buzz marketing strategy by industry players. Social media is one of the mainstay media for conducting buzz marketing practices and mapping the character of social media users to get the maximum impact from buzz [10]. In one research, it is crucial to bridge words through technology such as the internet, smartphones, computers, etc., and out-of-the-box thinking in maximizing this marketing practice [11]. Hennig-Thurau et al. tried to find out whether words spread through one of the microblogging sites, namely Twitter, could have an impact on the decision to watch a new film. They found evidence regarding the impact of Twitter for movie consumers towards the words spread through this platform [12].

Many variables can affect the buzz of a product. A study was conducted to determine the basis for buzz or viral marketing practice and determine the positives and negatives in driving a broad buzz marketing campaign. An honest and trusted word is the main attribute for a marketing strategy it can run successfully [13]. The equilibrium point of the buzz will depend on the presence and absence of hard-line followers for a product, and it can be found by modeling the collective behavior of consumers [14]. Another research was conducted to measure how the impact of image marketing practices, awareness, and buying decisions to understand and determine customer segments based on each consumer's expectations for a product [15]. The balance between positive and negative opinions will produce a more credible buzz or word of mouth [16]. A model to describe the relationship between the level of expertise and involvement of a consumer and the level of acceptance and use of word of mouth to make purchasing decisions were made. It was found that there were differences in shopping behavior between male and female consumers [17].

Influencers can be one of the primary mainstays in creating a big buzz and good word of mouth for a product. One research tries to find ways to choose people in the virtual world and the real world 
who want to share experiences and stories related to a brand or product [18]. Another research tries to see how influencers influence their Instagram followers considering the cultural changes in the millennial generation, especially women, and found the significant influence which later ultimately changed the marketing behavior of the products marketed through this platform [19].

The methods that can be used to create buzz or hype will vary in each industry. A study was conducted to see the impact of word of mouth on the imported shoe business [20]. Fuentes-Blasco et al. conducted an analysis related to the effects of consumer word of mouth on the success of brands and stores in the retail industry [21]. New media such as newspapers, blogs, and social media can be a new marketing tool to market products in theatre [22]. All of this proved that each industry has unique ways to create a Buzz regarding their products.

Although there have been several studies related to buzz marketing or the creation of word of mouth, there has been no research conducted to see how reviews, which are one of the main variables in making movie viewing decisions, can create buzz for a film. Regarding its concise life cycle, a film requires a much higher level of hype than other products. This study aims to see whose reviews create the hype that will maximize revenue from a film's short life cycle: film critics or fellow consumers.

The motion picture industry is a unique industry when compared to other industries in general. In addition to its concise life cycle, movies require a much higher level of buzz or hype to ensure a film to be successful in the market. The motion picture industry also has unique characteristics related to the reviews that consumers seek or use. In other industries, the clearer the review and the more expert the reviewer, the more confidence it increases. Movie premiere events are still limited to influencers or critics in the motion picture industry. Up until today it is very unlikely for the film producer to conduct a movie premiere event for the consumer. The rise in information technology has helped the buzz created by fellow consumers to maximize a new movie's awareness. This study will determine whose online reviews will influence the buzz or the hype from a movie, whether it is a review from fellow consumers or a review from movie critics.

\section{Research Methodology}

\subsection{Data and Variables}

To predict and see whose reviews will have a more significant influence on the potential hype of a film, several characteristics of the data will be used, including:

- There are two independent variables with interval data types: ratings from film critics and ratings from fellow viewers. In this study, the review used was taken from rottentomatoes.com, one of the principal online review aggregators used as a source of reviews by film audiences. Examples of reviews given by critics and consumers can be seen in Figure 2.
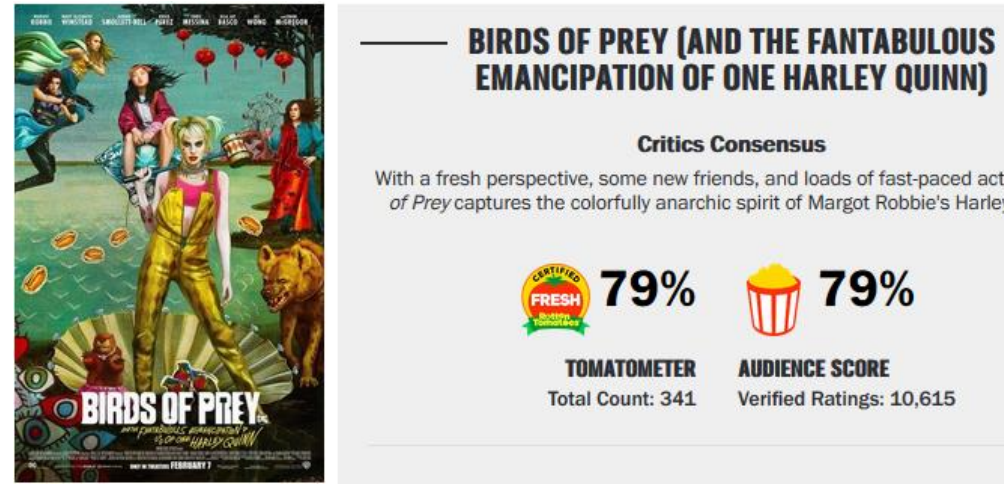

\section{EMANCIPATION OF ONE HARLEY QUINN]}

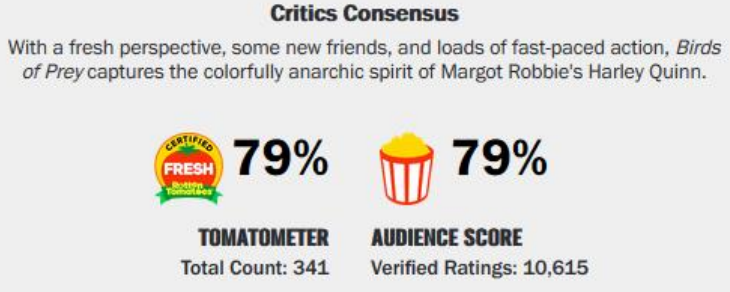

Figure 2. Reviews on rottentomatoes.com

- There is a variable of potential hype or excitement as the dependent variable, which will be measured by two questions, namely "How helpful do you think this film's rating is for other 
people?" and "After other people see the rating for this film, how much do you think they would like to watch this film?". These two questions will explain the hype creation process in the film industry. After seeing the rating of a movie, respondents will give their thoughts regarding the impact of the film's rating on other people. Then, they will represent their desire to provide advice or discuss the film's rating with others which will ultimately create hype and excitement for the film.

- Measurements of 219 samples were repeated under different conditions to record the responses of each respondent to varying reviews for a film.

- The measurement process is carried out repeatedly on the same sample. The data measurements were carried out on an ordinal scale. The statistical test chosen for this study is the Friedman 2 two-way ANOVA with ranks. The statistical test in this study was carried out using IBM's software output, namely SPSS.

\subsection{Sample and Population}

The population in this study were all Indonesian people who had and had a hobby of watching movies. Therefore, the sample used in this study was 219 students with an age range of 17-23 years, a generation that enjoys and is active in watching movies.

\subsection{Questionnaire}

The questionnaire will contain ten questions related to respondents' perceptions of a film review. This questionnaire will be administered using Google Forms for seven days period. This questionnaire will measure the respondents' responses for research question in 4 review conditions as the following:

- Condition 1 - Good critic reviews, bad consumer reviews

- Condition 2 - Bad critic reviews, good consumer reviews

- Condition 3 - Good critic reviews, good consumer reviews

- Condition 4 - Bad critic reviews, bad consumer reviews

The reviews categorized as bad are reviews with a score below 60 , while good reviews are scored greater than 60 . The reviews used in this study were taken from rottentomatoes.com because there are two reviews contained in rottentomatoes.com, namely reviews from critics who will be represented by the Tomatometer score and Audience Score, which is the value of fellow consumers. In Figure 2, it can be seen how the review is given on https://www.rottentomatoes.com/. In addition, each respondent will be given the opportunity to respond to the dependent variable in this study to measure the difference in the impact of reviews from critics and fellow consumers in the potential for hype or excitement for film products. Before the data obtained from this questionnaire is used and analyzed, validity and reliability tests will be carried out to ensure the reliability of the data that used in this study.

\section{Result and Discussion}

Data from 219 respondents were collected, and all of them were used for analysis in this study. Before the Friedman two way ANOVA test was carried out, the validity and reliability tests were conducted. The validity test shows a value above 0.812 for the first dependent variable question and 0.862 for the second dependent variable. Therefore, the questionnaire used to measure the dependent variable in this study is valid. Based on the reliability test, it was found that Cronbach's alpha value was 0.882 , which means the questionnaire used is reliable. The data generated from the questionnaire can be used to see better whose reviews can trigger hype or excitement in the film industry.

In this study, the potential for the hype of a film from a review is measured by two questions or dependent variables, which are:

1. How helpful do you think the film rating for other people?

2. After other people see the rating of this film, how much do you think they would like to see the film?

In the first question, the response from consumers in each condition will be measured using a Likert scale from 1-5, with 1 for the response is very helpful to 5 being very unhelpful. In the second question, a Likert scale of 1 will represent really wanting to watch movies up to 5 really not wanting to 
watch movies. These questions aim to see a person's perception and response when seeing a review of a film and to understand whose review is considered to be more able to help others in making better decisions when choosing what movies to watch and, in the end, will create hype or excitement for the film.

Table 1. Friedman's 2-way Anova DV 1 Test Results

\begin{tabular}{cccc}
\hline Null Hypothesis & Test & Sig & Decision \\
\hline The Distributions of & Related Samples & & \\
Condition 1 & Friedman's Two & & \\
Condition 2 & Way Analysis of &, 000 & Reject The Null \\
Condition 3 & Variance By & & Hypothesis \\
Condition 4 & Ranks & & \\
Are The Same & & & \\
& &
\end{tabular}

Table 1 shows in the first dependent variable, the significance value obtained from the Friedman 2-way ANOVA test is 0.000 , which means $\mathrm{HO}$ in this study which states there is no difference in the respondents' responses to the four review conditions described in the questionnaire can be rejected.

A pairwise comparison test was carried out to see and find a significant difference between the responses for each condition for the first dependent variable. The results of the pairwise comparison test for the dependent variable one can be seen in Table 2 and Figure 3.

Table 2. Pairwise comparison test results DV 1

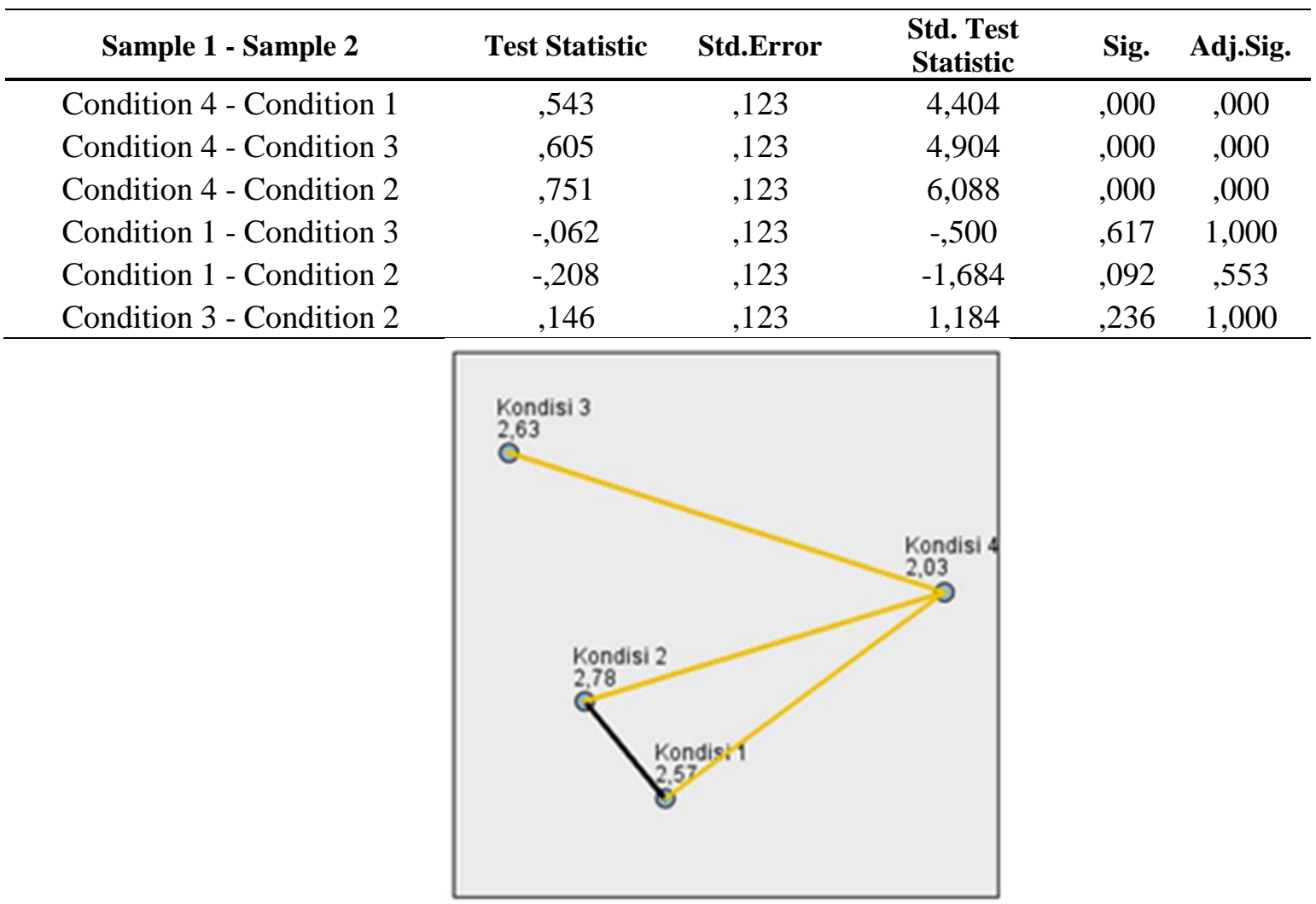

Figure 3. Pairwise comparison test DV 1 
From the pairwise comparison test results for the first dependent variable, it was found that a significant difference was in the response for condition four compared to the other three conditions so that a good review from consumers was perceived to be able to help other consumers more by the respondents.

Table 3. Friedman's 2-way Anova DV 2 Test Results

\begin{tabular}{cccc}
\hline Null Hypothesis & \multicolumn{1}{c}{ Test } & Sig & Decision \\
\hline The Distributions & & & \\
of & Related Samples & & \\
Condition 1 & Friedman's Two & & Reject The Null \\
Condition 2 & Way Analysis of &, 000 & Hypothesis \\
Condition 3 & Variance By & & \\
Condition 4 & Ranks & & \\
Are The Same & & & \\
\hline
\end{tabular}

Table 4. Pairwise comparison test results DV 2

\begin{tabular}{cccccc}
\hline Sample 1 - Sample 2 & Test Statistic & Std.Error & $\begin{array}{c}\text { Std. Test } \\
\text { Statistic }\end{array}$ & Sig. & Adj.Sig. \\
\hline Condition 4 - Condition 3 &, 594 &, 124 & 4,804 &, 000 &, 000 \\
Condition 4 - Condition 1 &, 894 &, 124 & 7,234 &, 000 &, 000 \\
Condition 4 - Condition 2 & 1,658 &, 124 & 13,410 &, 000 &, 000 \\
Condition 3 - Condition 1 &, 300 &, 124 & 2,430 &, 015 &, 091 \\
Condition 3 - Condition 2 & 1,064 &, 124 & 8,606 &, 000 &, 000 \\
Condition 1 - Condition 2 &,- 764 &, 124 & $-6,177$ &, 000 &, 000 \\
\hline
\end{tabular}

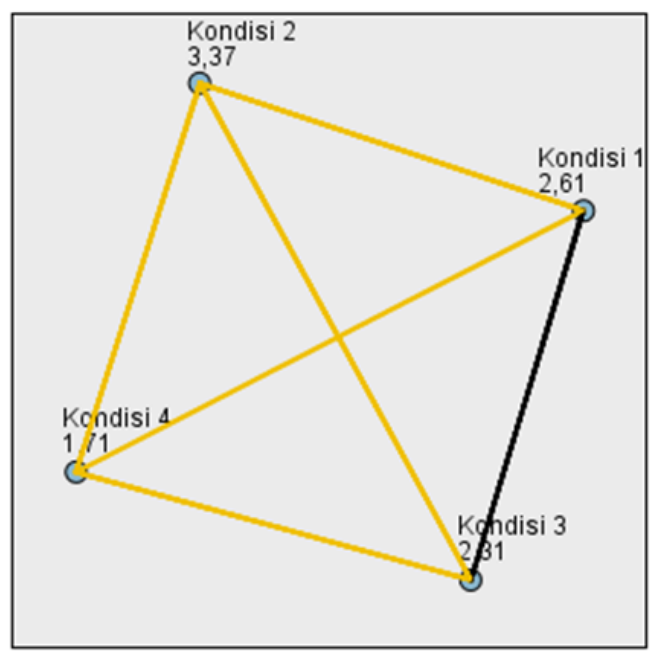

Figure 4. Pairwise comparison test DV 2

Figure 4 shows for the second dependent variable, the same procedure was also carried out. In the Friedman two way ANOVA test, a significance value of 0.000 was obtained. Thus, there were differences in the responses for each review condition presented to the respondents in this study. 
In the pairwise comparison test for the second dependent variable, there is a difference in the average response value between condition four and condition three, condition four with condition one, condition four with condition two, condition three with condition two and condition one with condition two. Pairwise comparison test results also show no significant difference in response between condition three and condition one.

\section{Conclusion}

With the increasingly intense competition in the film industry, choosing the right and precise marketing strategy is becoming increasingly crucial. One approach that production house owners always carry out is to screen films before their release to critics hoping that critics will give good reviews and create hype that can encourage more consumers to watch a movie and, of course, will increase revenue from the film.

This study tries to find out whether reviews from critics are enough to maximize the hype of a film and find that for respondents. The study found that a good review from fellow consumers will be more helpful for fellow consumers when compared to reviews from critics. So, if reviews from consumers are included in promotional practices before the film is released, it will maximize the hype for the film.

The results of this study also suggest a new marketing strategy for the film industry players, by screening films not limited only for critics but also for ordinary consumers who will also produce reviews. This review from fellow consumers in the end will create hype to maximize sales and revenue in a short film's life cycle.

\section{References}

[1] E. Fejza and A. Asllani, "the Importance of Marketing in Helping Companies With Their Growth Strategies : the Case of Food Industry in Kosovo," Eur. Sci. J., 2013.

[2] M. Nanda, C. Pattnaik, and Q. (Steven) Lu, "Innovation in social media strategy for movie success: A study of the Bollywood movie industry," Manag. Decis., vol. 56, no. 1, 2018, doi: 10.1108/MD-04-2017-0429.

[3] A. Watson, "Movie releases in North America from 2000-2019," Movie releases in North America from 2000-2019, 2020. https://www.statista.com/statistics/187122/movie-releases-innorth-america-since-2001/.

[4] L. Shackleton, "Is Indonesia the world's next big growth story?," Is Indonesia the world's next big growth story?, 2018. https://www.screendaily.com/features/is-indonesia-the-worlds-nextbig-growth-story/5134256.article.

[5] K. Salna, "Hollywood Finds a New Golden Age of Cinema in Indonesia," Hollywood Finds a New Golden Age of Cinema in Indonesia, 2019. .

[6] F. N. Ulya, "Pasar Industri Film Masih Terkendala Jumlah Bioskop," Pasar Industri Film Masih Terkendala Jumlah Bioskop, p. https://money.kompas.com/read/2019/07/09/213200426, 2019.

[7] D. Hofstrand, "Product Life Cycle," Product Life Cycle, 2017. .

[8] E. Ulker-Demirel, A. Akyol, and G. G. Simsek, "Marketing and consumption of art products: the movie industry," Arts Mark., vol. 8, no. 1, 2018, doi: 10.1108/aam-06-2017-0011.

[9] K. Armadani, "Cara XXI Menjaga Penayangan Film Indonesia," Cara XXI Menjaga Penayangan Film Indonesia, p. https://www.cnnindonesia.com/hiburan/2014083012334, 2014.

[10] K. M. R. Taufique and F. M. Shahriar, "Online Social Media as a Driver of Buzz Marketing," Int. J. Online Mark., 2011, doi: 10.4018/ijom.2011040104.

[11] I. Mohr, "Managing Buzz Marketing in the Digital Age," J. Mark. Dev. Compet., 2017.

[12] T. Hennig-Thurau, C. Wiertz, and F. Feldhaus, "Does Twitter matter? The impact of microblogging word of mouth on consumers' adoption of new movies," J. Acad. Mark. Sci., 2015, doi: 10.1007/s11747-014-0388-3.

[13] B. Rollins, I. Anitsal, and M. M. Anitsal, "Viral marketing: Techniques and implementation," Entrep. Exec., 2014.

[14] J. Oheki, "Analysis of the buzz formation model: New marketing approch," Inf., 2014. 
[15] C. Leila and G. Abderrazak, "The Impact of the Effectiveness of a Buzz Marketing Campaign on the Image, Awareness and Purchasing Decision: The Moderating Role of Involvement," J. Mark. Res. Case Stud., 2013, doi: 10.5171/2013.584547.

[16] W. J. Carl, "What's all the buzz about?: Everyday Communication and the Relational Basis of Word-of-Mouth and Buzz Marketing Practices," Manag. Commun. Q., 2006, doi: $10.1177 / 0893318905284763$.

[17] Y.-W. Fan and Y.-F. Miao, "EFFECT OF ELECTRONIC WORD-OF-MOUTH ON CONSUMER PURCHASE INTENTION: THE PERSPECTIVE OF GENDER DIFFERENCES," Int. J. Electron. Bus. Manag., 2012.

[18] J. Sorokin, "Strategies for choosing influentials in buzz marketing," J. Int. Stud., 2012, doi: 10.14254/2071-8330.2012/5-2/9.

[19] D. Mathew, Micro-Celebrity Influencer Marketing: The Impact of Instagram Influencers on Consumer Culture of Young Millennial Women. 2019.

[20] J. Syahrivar and A. M. Ichlas, "The Impact of Electronic Word of Mouth (E-WoM) on Brand Equity of Imported Shoes: Does a Good Online Brand Equity Result in High Customers' Involvements in Purchasing Decisions?," Asian J. Technol. Manag., 2018, doi: 10.12695/ajtm.2018.11.1.5.

[21] M. Fuentes-Blasco, B. Moliner-Velázquez, D. Servera-Francés, and I. Gil-Saura, "Role of marketing and technological innovation on store equity, satisfaction and word-of-mouth in retailing," J. Prod. Brand Manag., vol. 26, no. 6, 2017, doi: 10.1108/JPBM-07-2016-1279.

[22] R. T. Warne and M. M. Drake-Brooks, "Comparing the persuasiveness and professionalism of newspaper, blog, and social media sources of information in marketing and reviewing theatre," Arts Mark., 2016, doi: 10.1108/aam-03-2015-0004. 